Available online at: https://jurnal.unej.ac.id/index.php/JLC
LEARNING COMMUNITY
Jurnal Pendidikan Luar Sekolah, 4 (1), 2020, 16-19

\title{
Pengolahan Limbah Ikan Terhadap Keberdayaan Masyarakat Pesisir Di Dusun Sampangan Desa Kedungrejo Kecamatan Muncar Kabupaten Banyuwangi
}

\author{
Moh. Nur Pramana Putra, Niswatul Imsiyah, Lutfi Ariefianto \\ Pendidikan Luar Sekolah, Universitas Jember. Jl. Kalimantan No. 37, Tegal Boto, Jember 62811, Indonesia \\ Email : putra.deus12@gmail.com
}

\begin{abstract}
Abstrak
Kehidupan masyarakat pesisir Desa Kedungrejo Kecamatan Muncar yang mana sebagian besar penduduk di daerah pesisir tersebut bermata pencaharian di sektor pemanfaatan sumber daya kelautan seperti nelayan, pengolahan ikan dan jenis industri ikan lainnya.Namun yang perlu di perhatikan dalam hal ini bahwa potensi kelautan dan pesisir yang besar ini belum sepenuhnya dimanfaatkan secara optimal. Tujuan dari penelitian ini adalah untuk mengetahui seberapa besar hubungan antara pengolahan limbah ikan dengan keberdayaan masyarakat pesisir di Dusun Sampangan Desa Kedungrejo Kecamatan Muncar Kabupaten Banyuwangi Manfaat dari penelitian ini memberikan pemahaman bahwa pengolahan hasil dari limbah ikan akan mampu memberikan manfaat yang positif bagi masyarakat sekitar dalam hal perbaikan pendapatan dan perbaikan lingkungan. Jenis penelitian ini adalah penelitian korelasional dengan pendekatan kuantitatif. Teknik pengumpulan data yang digunakan peneliti yakni melalui angket, observasi dan dokumentasi. Teknik analisis data yang digunakan peneliti yakni dengan menggunakan rumus korelasi tata jenjang yang dibantu dengan menggunakan alat bantu SPSS (Statistical Package for the Social) seri 24. Hasil penelitian dapat disimpulkan bahwa terdapat hubungan antara pengolahan limbah ikan dengan keberdayaan masyarakat pesisir di dusun sampangan desa kedungrejo kecamatan muncar kabupaten banyuwangi dengan angka koefisien korelasi sebesar 0,651.
\end{abstract}

Kata Kunci: Pengolahan limbah ikan, Keberdayaan masyarakat, Keterampilan, Pengetahuan.

\section{The Process of Fish Waste to Coastal Community Empowerment in Sampangan Hamlet in Kedungrejo Village, Muncar Banyuwangi Regency \\ Abstract}

The life of the coastal community in Kedungrejo Village, Muncar Subdistrict, where most of the residents in the coastal area make a living in the sector of marine resource utilization such as fishermen, fish processing and other types of fish industry. this has not been fully utilized optimally. The purpose of this research is to find out how big the relationship between fish waste treatment and the empowerment of coastal communities in the Sampangan Hamlet, Kedungrejo Village, Muncar District, Banyuwangi Regency. The benefits of this study provide an understanding that processing results from fish waste will be able to provide positive benefits for the surrounding community in terms of improved income and environmental improvement. This type of research is correlational research with a quantitative approach. Data collection techniques used by researchers namely through a questionnaire, observation and documentation. The data analysis technique used by researchers is to use the formula for the correlation of levels which is assisted by using SPSS (Statistical Package for the Social) series 24. The results of this study can be concluded that there is a relationship between fish waste treatment and the empowerment of coastal communities in the hamlet of Kedungrejo village Kecamatan Muncar Banyuwangi with a correlation coefficient of 0.651 .

Keywords: : Fish waste treatment, Community empowerment, skills, knowledge. 


\title{
Learning Community: Jurnal Pendidikan Luar Sekolah, 4 (1), Maret 2020 - 17
}

\author{
Moh. Nur Pramana Putra
}

\section{PENDAHULUAN}

Limbah merupakan buangan dari sisa barang dan benda yang tidak di pergunakan lagi dan buangan dari hasil produksi yang sudah tidak di manfaatkan. Semakin banyak limbah akan menyebabkan dampak terhadap lingkungan, sehingga perlu pengolahan limbah untuk mengurangi dampaknya. Limbah sendiri sebenarnya masih bisa dimanfaat lagi dengan mendaur ulang atau mengolahnya lagi, dengan adanya limbah masyarakat sendiri bisa memanfaatkan dan mengolah limbah buangan sehingga mempunyai nilai ekonomi, Potensi limbah yang ada di masyarakat pesisir di Desa Kedungrejo berupa limbah ikan.

Ikan yang di tangkap dikirim langsung ke pabrik - pabrik besar untuk di olah. Dari olahan tersebut terdapat limbah atau bagian - bagian ikan yang di buang seperti kepala, tulang dan ikan yang tidak layak di olah, diambil untuk di olah menjadi suatu bernilai ekonomi seperti tepung dan minyak ikan. Sumber kehidupan ekonomi masyarakat pesisir Desa Kedungrejo Kecamatan Muncar yang notabene nelayan bergantung secara langsung dari hasil laut, namun dari banyaknya nelayan tidak sedikit pula yang pulang tanpa memperoleh tangkapan ikan dan tidak semua masyarakat bisa berlayar. Sehingga untuk memenuhi kebutuhan hidup sehari - hari, mereka harus bekerja di pabrik - pakbik ikan dan pabrik pengolah limbah ikan. Lingkungan di pesisir Desa Kedungrejo Kecamatan Muncar sendiri sudah tercemar limbah pabrik hasil industri ikan, sehingga untuk mengurangi pencemaran yang berlebihan limbah ikan sendiri harus bisa di manfaatkan dan di olah kembali guna menjadi nilai ekonomi.

Perberdayaan tidak boleh menciptakan ketergantungan, tetapi harus mampu mendorong semakin terciptanya kreativitas dan kemandirian masyarakat. Kerusakan lingkungan laut yang terjadi karena fenomena alam dan juga karena kegiatan manusia itu sendiri seperti pembuangan limbah ikan yang berlebihan yang berdampak pada kerusakan lingkungan, dengan adanya kegiatan pengolahan limbah ikan yang di lakukan masyarakat pesisir Desa Kedungrejo Kecamatan Muncar yang mana masyarakat sendiri terbantu dalam faktor ekonomi dan mencegah atau meminimalisir pencemaran lingkungan.

Berdasarkan latar belakang di atas, peneliti merumuskan masalah yaitu seberapa besar hubungan antara pengolahan limbah ikan dengan keberdayaan masyarakat pesisir di Dusun Sampangan Desa Kedungrejo Kecamatan Muncar Kabupaten Banyuwangi?. tujuan dari penelitian ini adalah untuk mengetahui seberapa besar hubungan antara pengolahan limbah ikan dengan keberdayaan masyarakat pesisir di Dusun Sampangan Desa Kedungrejo Kecamatan Muncar Kabupaten Banyuwangi. Manfaat dari penelitian ini diharapkan dapat dijadikan pedoman maupun perbandingan bagi peneliti lain yang ingin meneliti kaitannya dengan pemberdayan masyarakat, khususnya yang meneliti tentang hubungan antara keberdayaan masyarakat pesisir dengan pengolahan hasil potensi lokal.

\section{METODE}

Penelitian ini merupakan jenis penelitian korelasional dengan pendekatan kuantitatif. Penelitian ini dilakukan selama 9 bulan, dimulai bulan Desember 2018 sampai dengan Agustus 2019 di Dusun Sampangan Desa kedungrejo kecamatan Muncar kabupaten Banyuwangi sebagai daerah yang dipilih untuk tempat penelitian dengan menggunakan teknik purposive area. Sedangkan untuk pengumpulan datanya menggunakan kuesioner atau angket dan dokumentasi.

Pengumpulan data di atas selanjutnya dibuktikan melalui pengisian angket dengan menggunakan checklist kepada 24 responden penelitian yaitu masyarakat pesisir dusun sampangan yang melakukan pengolahan limbah ikan. Penentuan responden penelitian menggunakan teknik populasi. Dalam pengisian angket menggunakan checklist dengan 16 butir pernyataan selanjutnya dilakukan persiapan, tabulasi, coding dan scoring. Jika keseluruhan item pernyataan tersebut sudah terisi, maka akan dilakukan analisis data lebih lanjut dengan menggunakan rumus korelasi tata jenjang.

\section{HASIL DAN PEMBAHASAN}

Hasil penelitian dibuktikan melalui proses analisis data menggunakan rumus 


\title{
Learning Community: Jurnal Pendidikan Luar Sekolah, 4 (1), Maret 2020 - 18
}

\author{
Moh. Nur Pramana Putra
}

korelasi tata jenjang pada hasil pengisian angket berupa checklist yang telah dilakukan. Adapun hasil perhitungan yang diperoleh

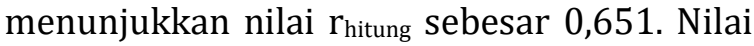
tersebut lebih besar dari $r_{\text {tabel }}$ sebesar 0,409 (dengan $\mathrm{N}=24$ pada taraf kepercayaan 95\%). hal ini dapat dikatakan bahwa pengolahan limbah ikan dengan keberdayaan masyarakat pesisir memiliki hubungan yang tinggi. Hasil tersebut diperjelas kembali melalui hasil analisis data terhadap masing-masing indikator yang dijelaskan sebagai berikut.

Berdasarkan hasil olahan data menunjukkan bahwa variabel XI (Pengetahuan) dengan variabel $Y$ (Keberdayaan Masyarakat Pesisir) sebesar 0,524 dengan signifikasi $0,000<0,05$ yang berarti bahwa terdapat hubungan antara pengetahuan dengan keberdayaan masyarakat pesisir di Dusun Sampangan Desa Kedungrejo Kecamatan Muncar Kabupaten Banyuwangi memiliki hubungan yang cukup, sedangkan variabel X2 (Keterampilan) dengan variabel Y (Keberdayaan Masyarakat Pesisir) sebesar 0,613 dengan signifikasi $0,000<0,05$ yang berarti bahwa terdapat bahwa hubungan antara keterampilan dengan keberdayaan masyarakat pesisir di Dusun Sampangan Desa Kedungrejo Kecamatan Muncar Kabupaten Banyuwangi memiliki hubungan yang tinggi.

Berdasarkan hasil penelitian yang telah dilakukan, maka dapat diketahui bahwa ada hubungan antara yang tinggi antara pengolahan limbah ikan terhadap keberdayaan masyarakat Pesisir Dusun Sampangan Desa Kedungrejo Kecamatan Muncar Kabupaten Banyuwangi.

Pada dasarnya pengolahan limbah bukanlah hal yang sulit dilakukan, namun demikian pelaksanaannya perlu kesungguhan dan niat untuk menyelamatkan lingkungan kita dari berbagai pencemar yang dapat mencemari air, tanah dan udara (Siahan, 2008:2). Dalam hal ini, keberdayaan masyarakat perlu ditingkatkan guna mencapai eksistensi masyarakat dalam konteks meningkatkan posisi tawar dalam pengambilan keputusan dalam lingkup industri pengolahan limbah ikan. Upaya mentransfer pengetahuan dan keterampilan kepada masyarakat dalam pengolahan limbah ikan merupakan agenda penting. Selain itu, pengolahan limbah ikan dapat menjadi sumber ekonomi masyarakat sekitar yang perlu ditingkatkan kapasitasnya (Sulistiyani, 2016:19).

Sedangkan untuk analisis dari setiap indikator adalah: untuk indikator Pengetahuan terhadap Keberdayaan Masyarakat Pesisir memiliki tingkat hubungan yang cukup. Hasil temuan ini membuktikan bahwa faktor yang mempengaruhi peningkatan pengetahuan seseorang antara lain adalah didapatkan sebuah informasi karena akan memberi pengaruh pada pengetahuan pada pengetahuan seseorang (Novita, 2014:14). Sehingga pengetahuan sangat berperan penting dalam memberdayakan masyarakat pesisir, salah satunya dengan memberi pengetahuan kepad[a masyarakat pesisir bagaimana mengelola limbah ikan menjadi suatu yang bernilai ekonomis. Untuk indikator keterampilan dengan keberdayaan masyarakat pesisir memiliki tingkat hubungan yang sangat tinggi $\mathrm{Hal}$ ini menunjukkan bahwa keterampilan sebagai kemampuan seseorang terhadap suatu hal yang meliputi semua tugas-tugas kecakapan, sikap,nilai dan kemengertian yang semuanya dipertimbangkan sebagai sesuatu yang penting untuk menunjang keberhasilannya di dalam penyelesaian tugas (Mustafa, 2017:3839). Maka dalam mensejahterakan kehidupan masyarakat pesisir untuk mengarah yang lebih berdaya, masyarakat pesisir harus mampu menerapkan kemampuan potensi diri mereka dan melihat peluang disekitar, salah satunya dalam mengolah limbah ikan menjadi sesuatu yang memiliki nilai ekonomis tinggi.

\section{SIMPULAN}

Kesimpulan dari penelitian ini yaitu hubungan kedua variabel yaitu Pengolahan Limbah Ikan Dengan Keberdayaan Masyarakat Pesisir di Dusun Sampangan Kelurahan Kedungrejo Kabupaten Banyuwangi memiliki hubungan yang tinggi. Dengan demikian dapat dikatakan bahwa pengolahan limbah ikan memiliki hubungan yang tinggi terhadap keberdayaan masyarakat pesisir di Dusun Sampangan Kelurahan Kedungrejo Kabupaten Banyuwangi. 
Learning Community: Jurnal Pendidikan Luar Sekolah, 4 (1), Maret 2020 - 19 Moh. Nur Pramana Putra

\section{DAFTAR PUSTAKA}

Mustafa, Habibullah. 2017. Evaluasi Terhadap Program Pelatihan Keterampilan Pada Institut Kemandirian Dompet Dhuafa Tangerang. Skripsi. Jakarta: Universitas Islam Negeri Syarif Hidayatullah.

Novita, Ita. 2014. Kontribusi Peran Kelompok Tani Terhadap Keberdayaan Masyarakat Di Dusun Balerejo Desa Bumiharjo Kecamatan Glenmore Kabupaten Banyuwangi. Skripsi. Jember: Universitas Negeri Jember
Siahaan. 2008. Hukum Lingkungan. Jakarta: Pancuran Alam.

Sulistiyani, Ambar Teguh., dkk. 2016. Pemberdayaan Masyarakat Pemanfaatan Tulang Ikan Untuk Produk Hidroksiapatit (Hydroxyapatite/HA) Kajian di Pabrik Pengolahan Krupuk Lekor Kuala Trengganu - Malaysia. 2016. Jurnal of Community Engagement. 02(01): 14 29 